\title{
The combined treatment with chloroquine and the enzymatic oxidation products of spermine overcomes multidrug resistance of melanoma M14 ADR2 cells: A new therapeutic approach
}

\author{
ENZO AGOSTINELLI ${ }^{1}$, MARIA CONDELLO $^{2}$, GIAMPIERO TEMPERA $^{1}$, ALBERTO MACONE $^{1}$, \\ GIUSEPPINA BOZZUTO ${ }^{2}$, SHINJI OHKUBO ${ }^{1}$, ANNARICA CALCABRINI ${ }^{2}$, \\ GIUSEPPE ARANCIA ${ }^{2}$ and AGNESE MOLINARI ${ }^{2}$ \\ ${ }^{1}$ Istituto Pasteur-Fondazione Cenci Bolognetti and Department of Biochemical Sciences, \\ Sapienza University of Rome and CNR, I-00185 Rome; ${ }^{2}$ Department of Technology \\ and Health, Italian National Institute of Health, I-00161 Rome, Italy
}

Received March 12, 2014; Accepted May 2, 2014

DOI: $10.3892 /$ ijo.2014.2502

\begin{abstract}
It has been confirmed that multidrug resistant (MDR) melanoma cells (M14 ADR2) are more sensitive than their wild-type counterparts (M14 WT) to $\mathrm{H}_{2} \mathrm{O}_{2}$ and aldehydes, the products of bovine serum amine oxidase (BSAO)-catalyzed oxidation of spermine. The metabolites formed by BSAO and spermine are more toxic, in $\mathrm{M} 14$ cells, than exogenous $\mathrm{H}_{2} \mathrm{O}_{2}$ and acrolein, even though their concentration is lower during the initial phase of incubation due to their more gradual release than the exogenous products. Binding of BSAO to the cell membrane and release of the reaction products of spermine into the immediate vicinity of the cells, or directly into the cells, may explain the apparently paradoxical phenomenon. Both
\end{abstract}

Correspondence to: Professor Enzo Agostinelli, Department of Biochemical Sciences 'A. Rossi Fanelli', Sapienza University of Rome, Piazzale A. Moro 5, I-00185 Rome, Italy

E-mail: enzo.agostinelli@uniroma1.it

Abbreviations: ADR, adriamycin; AO, amine oxidase; BSA, bovine serum albumin; BSAO, bovine serum amine oxidase; $\mathrm{CQ}$, chloroquine; DMSO, dimethyl sulfoxide; DOX, doxorubicin; EDTA, ethylenediaminetetraacetic acid; FAD, flavin-adenin-dinucleotide; FBS, foetal bovine serum; FITC, fluoresceine isothiocyanate conjugated; HEPES-BSS, HEPES-buffered balanced salt solution; IU, international units; LSCM, laser scanning confocal microscopy; MFC, means fluorescence channel; MDL 72527, $\left[\mathrm{N}^{1}, \mathrm{~N}^{4}\right.$-bis(2,3-butadienyl)1,4-butanediamine dihydrochloride]; MDR, multidrug resistance; PBS, phosphate-buffered saline; P-gp, P-glycoprotein; PI, propidium iodide; RNAse A, ribonuclease A; ROS, reactive oxygen species; SEM, scanning electron microscopy; SD, standard deviation; SDS/PAGE, sodium dodecyl sulphate/polyacrylamide gel electrophoresis; Spm, spermine; TEM, transmission electron microscopy; WT, wild-type

Key words: spermine, melanoma, melanocytes, amine oxidase, cytotoxicity, lysosomotropic compounds
WT and MDR cells, after pre-treatment for $24 \mathrm{~h}$, or longer, with the lysosomotropic compound chloroquine (CQ), show to be sensitized to subsequent exposure to $\mathrm{BSAO} /$ spermine enzymatic system. Evidence of ultrastructural aberrations and acridine orange release from lysosomes is presented in this study that is in favor of the permeabilization of the lysosomal membrane as the major cause of sensitization by CQ. Pre-treatment with CQ amplifies the ability of the metabolites formed from spermine by oxidative deamination to induce cell death. Melanocytes, differently from melanoma cells, were unaffected by the enzymatic system, even when preceded by CQ treatment. Since it is conceivable that combined treatment with a lysosomotropic compound and $\mathrm{BSAO} /$ spermine would be effective against tumour cells, it is of interest to search for such novel compounds, which might be promising for application in a therapeutic setting.

\section{Introduction}

Malignant melanoma and treatment failure are, unluckily, two intertwined clinical problems with a profound social impact. The lifetime risk of melanoma continues to increase steadily. Unfortunately, melanoma lesions can remain unnoticeable or asymptomatic for extended periods of time. Melanoma can generate metastasis at stage IV, without a clearly identifiable primary lesion.

The success of systemic therapy for melanoma has been minimal, because melanoma is an extremely aggressive disease with high metastatic potential and a high resistance to cytotoxic agents. Indeed, it is notoriously high resistant to standard drugs, such as nitrosoureas, vinca alkaloids, platinum-associated drugs and anthracyclines antibiotic, like doxorubicin. A body of literature data has described several mechanisms and factors implicated in the resistance of malignant melanoma. In particular, the multidrug resistant (MDR) phenotype can be costitutively expressed by melanoma cells. It is mediated by the overexpression of ATP-binding cassette (ABC) transporters 
such as ABCA9, ABCB1/P-gp, ABCB5, ABCB8, ABCC1, $\mathrm{ABCC} 2$ and $\mathrm{ABCD} 1$, that efflux anticancer drugs from cells and reduce their concentration and cytotoxic effect $(1,2)$. Moreover, constitutively activated Ras/Raf/MEK/ERK (MAPK) and the PI3K/AKT (AKT) signaling pathways strongly contribute to confer resistance to the apoptotic death (3).

A broad spectrum of targeted therapeutic strategies, including targeting of the anti-apoptotic proteins, signal transduction pathways and tumour angiogenesis factors, are currently being studied in clinical trials (4). Unfortunately, in conventional cancer chemotherapy, all the therapies contribute scarsely to overall patient survival. Numerous difficulties prevent successful treatment, such as the poor selectivity of the cytotoxic drugs for tumours and the development of MDR of cancer cells, which represent the most difficult problems to solve. Thus, alternative therapeutic strategies are required. In the development of new treatments against tumours the differences between normal and cancer cells must be considered.

One such difference is the polyamine content and metabolism $(5,6)$. The content of polyamines, such as putrescine, spermidine and spermine (Spm), is increased in tumour cells in comparison with their normal counterparts. Increased polyamine levels are associated with increased cell proliferation, decreased apoptosis and down-expression of genes affecting tumour invasion and metastasis (7). Moreover, the natural polyamines are also source of cytotoxic metabolites, because they are substrates of a large class of enzymes, named amine oxidases. Our previous studies demonstrated that these enzymes catalyze the oxidative deamination of polyamines to generate cytotoxic products, $\mathrm{H}_{2} \mathrm{O}_{2}$ and aldehydes, that induce apoptotic and non-apoptotic cell death. Such products also proved to induce a higher cell death on MDR melanoma cells than on the corresponding wild-type cells $(8,9)$. It was demonstrated that the combination of BSAO/Spm with either docetaxel or interferon $\alpha$ had a synergistic effect on the inhibition of cell growth through apoptosis in both human epidermoid KB and breast cancer MCF-7 cell lines $(10,11)$.

Noteworthy, our previous studies demonstrated that the induction of cell death, in colon adenocarcinoma (LoVo) and melanoma (M14) cancer cells, was potentiated by the combined treatments of BSAO/Spm with MDL $72527\left[\mathrm{~N}^{1}, \mathrm{~N}^{4}\right.$-bis $(2,3-$ butadienyl)-1,4-butanediamine dihydrochloride], an inactivator of flavin-adenin-dinucleotide (FAD)-dependent amine oxidase (AO) with lysosomotropic properties $(8,9,12,13)$. Thus, the aim of this study was to verify if also CQ, a well known lysosomotropic compound, was able to sensitize tumour cells to the cytotoxic activity of spermine metabolites (14). Chloroquine, 4-aminoquinoline, is a drug widely used for the therapy of malaria and as an anti-inflammatory agent for the treatment of several diseases such as rheumatoid arthritis, lupus erythematosus and amoebic hepatitis, by targeting the polyamine pathway.

A systematic exploration of the potential of this category of compounds in cancer therapy seems of interest. In fact, CQ has been studied for its potential as an enhancing agent in cancer therapies. Therefore, in the present study, the effect of pre-treatment with CQ on the cytotoxicity of the spermine metabolites was evaluated on wild-type human melanoma cells (M14 WT) and the corresponding doxorubicin-induced MDR cells (M14
ADR2). The type of the induced cell death, the mechanism of action and the main intracellular targets were investigated. Moreover, the possible cytotoxicity of spermine metabolites on melanocytes were also studied, in order to exclude undesired side effects in view of future clinical applications.

\section{Materials and methods}

Chemicals. If not stated otherwise chemicals were from Sigma Chemical Co. (St. Louis, USA). Spermine tetrahydrochloride was from FLUKA (Buchs, Switzerland), doxorubicin (DOX) was from Pharmacia and Upjohn (Milan, Italy). Chloroquine (CQ) diphosphate salt was from Sigma product of United Kingdom.

Purification of BSAO. BSAO was purified to homogeneity essentially as described by Turini et al (15) with additional ion exchange chromatographic steps as described previously by Janes et al (16). The purified enzyme moved as a single band on sodium dodecyl sulphate (SDS)/PAGE and all samples employed had a minimum specific benzylamine oxidase activity of $0.38 \mathrm{IU} / \mathrm{mg}$, with international unit (IU) defined as micromoles of substrate oxidized per min, assayed spectrophotometrically at $25^{\circ} \mathrm{C}$ by monitoring the formation of benzaldehyde at $250 \mathrm{~nm}$ absorbance $(\varepsilon=12,500 / \mathrm{M} / \mathrm{cm})$. The protein concentration was determined spectrophotometrically at $280 \mathrm{~nm}$, assuming an absorption coefficient of $1.741 / \mathrm{g} / \mathrm{cm}$.

Melanoma cells and culture conditions. The parental human M14 cell line, isolated from an epidermal melanoma, and the corresponding MDR variant M14 ADR2 were used in the present investigation. The resistant cell line M14 ADR2 was obtained by us culturing the M14 ADR cell line, previously selected by Molinari et al (17), in medium containing $10 \mu \mathrm{M}$ doxorubicin (DOX) constantly, in each passage. Both resistant lines display multidrug resistant phenotype being, in addition to DOX, also resistant to other chemotherapeutic agents. Cells were grown in monolayer in Falcon flasks (initial cell number $8 \times 10^{5}$ ) in RPMI-1640 (with glutamine), $10 \%$ foetal bovine serum (FBS) (Hyclone, Europe Ltd., Cramlington, UK), penicillin $(50 \mathrm{U} / \mathrm{ml})$, streptomycin $(50 \mu \mathrm{g} / \mathrm{ml})$ and non-essential amino acids in the same concentration as streptomycin, in a humidified atmosphere of $5 \% \mathrm{CO}_{2}$ in a waterjacketed incubator at $37^{\circ} \mathrm{C}$.

Melanocyte culture. Normal human epidermal melanocytes (NHEM) were cultured in PromoCell Melanocyte Growth Medium M2 (is a serum-free) and Supplement Mix C-39420 (PromoCell, Heidelberg, Germany). Briefly, cryopreserved primary melanocytes were transferred into tissue culture Falcon flasks at a density of $5 \times 10^{5}$ cells $/ 25 \mathrm{~cm}^{2}$ and were grown in melanocyte growth medium in a humidified atmosphere of $5 \% \mathrm{CO}_{2}, 95 \%$ air in a waterjacketed incubator at $37^{\circ} \mathrm{C}$. The culture medium was changed every other day. After cells became semiconfluent the medium was removed and melanocytes were subcultured. The Detach kit consists of three components: i) HEPES-BSS (HEPES-buffered balanced salt solution); ii) $0.04 \%$ Trypsin/0.03\% EDTA; 3) $0.05 \%$ Trypsin inhibitor, $0.1 \%$ BSA. All solutions were stored at $-20^{\circ} \mathrm{C}$ in the dark immediately after arrival. 
Cell viability: clonogenic assay. Cell viability assays were carried out using subconfluent cells. Cells were detached by addition of $10 \mathrm{mM}$ EDTA in phosphate-buffered saline (PBS), washed with PBS supplemented with $1 \%$ bovine serum albumin (BSA) and pelleted by centrifugation ( $2 \mathrm{~min}$, $1500 \mathrm{x}$ g). The cells were re-suspended in PBS/BSA. Aliquots of freshly harvested M14 cells $\left(10^{5} / \mathrm{ml}\right)$ were incubated at $37^{\circ} \mathrm{C}$ for different time intervals in the presence of the following reagents, used alone or in association: BSAO $(17.20 \mu \mathrm{g} / \mathrm{ml}$ corresponding to $1.01 \times 10^{-4} \mu$ moles $/ \mathrm{ml}$ or $6.5 \times 10^{-3} \mathrm{IU} / \mathrm{ml}$ ), spermine (up to $6 \mu \mathrm{M}$ ). The spermine solution was freshly prepared before each experiment and, if present, added last. Other cell survival experiments were performed using subconfluent cells that had been incubated for $24 \mathrm{~h}$ in RPMI-1640 medium containing $\mathrm{CQ}$ at $50 \mu \mathrm{M}$, in the presence of serum, at $37^{\circ} \mathrm{C}$. Incubation was carried out as described above, in the presence or absence of BSAO/spermine. After incubation the cells were centrifuged, washed twice in PBS/BSA and re-suspended in $1 \mathrm{ml}$ PBS/BSA. Cytotoxicity was evaluated by a plating efficiency assay, which determines the ability of the cells to form macroscopic colonies (>50 cells). Aliquots of cell suspensions containing $10^{5}$ cells $/ \mathrm{ml}$ were plated in tissue culture dishes $(50 \mathrm{~mm} \varnothing)$ containing $5 \mathrm{ml}$ complete culture medium and were incubated at $37^{\circ} \mathrm{C}$. After 14 days, the colonies were fixed with $96 \%$ ethanol, stained with methylene blue and counted. Control plating efficiencies were $>85$ and $80 \%$, for M14 WT and M14 ADR2 cells, corresponding to $9.1 \times 10^{4} \pm 1.0 \times 10^{4}$ and $8.5 \times 10^{4} \pm 1.0 \times 10^{4}$ number of cells, respectively. The percentage of colony forming cells was determined as the ratio between the mean number of colonies in treated and control samples.

Cell viability: MTT assay. M14 cells and melanocytes were seeded at $1 \times 10^{4}$ density in 96 -well plates and pre-treated with various concentrations of CQ $(0-50 \mu \mathrm{M})$ for $24 \mathrm{~h}$ and then with $\mathrm{BSAO} /$ spermine for $1 \mathrm{~h}$, at $37^{\circ} \mathrm{C}$. Cells were exposed to $10 \mu \mathrm{l}$ of 3-(4,5-dimethylthiazol-2-yl)-2,5-diphenyltetrazolium bromide dye $(5 \mathrm{mg} / \mathrm{ml})$ and were incubated at $37^{\circ} \mathrm{C}$ for $4 \mathrm{~h}$ for the conversion of MTT to MTT-formazan crystals by mitochondrial enzymes. In order to solubilize the formazan crystals, $100 \mu 1$ DMSO was added. Absorbance was determined at $570 \mathrm{~nm}$ with the spectrophotometer mod. Perkin-Elmer $\lambda 11$ (Bio-Rad, Hercules, CA, USA).

Scanning electron microscopy (SEM). For SEM studies, control and treated cells were grown on coverslips and fixed with $2.5 \%$ glutaraldehyde in $0.1 \mathrm{M}$ cacodylate buffer ( $\mathrm{pH} 7.3$ ), added with $2 \%$ sucrose, at room temperature for $20 \mathrm{~min}$. After post-fixation with $1 \% \mathrm{OsO}_{4}$ in $0.1 \mathrm{M}$ cacodylate buffer $(\mathrm{pH} \mathrm{7.3)}$ at room temperature for $30 \mathrm{~min}$, cells were dehydrated through graded ethanol concentrations, critical point-dried in $\mathrm{CO}_{2}$ (CPD 030 Balzers device, Bal-Tec, Balzers) and gold coated by sputtering (SCD040 Balzers device, Bal-Tec). The samples were then examined with a Cambridge Stereoscan 360 scanning electron microscope (Cambridge Instruments, Cambridge, UK).

Transmission electron microscopy (TEM). Transmission electron microscopy observations were performed using confluent cells that had been incubated for $24 \mathrm{~h}$ in RPMI-1640 medium containing CQ at $50 \mu \mathrm{M}$, in the presence of serum, at $37^{\circ} \mathrm{C}$. Then, cells were harvested as described above, washed with PBS/1\% BSA, centrifuged and re-suspended in $2 \mathrm{ml}$ of RPMI-1640 medium (without FBS). After incubation for $60 \mathrm{~min}$ at $37^{\circ} \mathrm{C}$ in the presence or absence of $\operatorname{BSAO}\left(6.5 \times 10^{-3} \mathrm{IU} / \mathrm{ml}\right)$ and spermine $(6 \mu \mathrm{M})$, cells were washed with RPMI-1640 medium and then processed for TEM, as described previously by Molinari et al (18). Ultrathin sections were examined with a Philips EM 208S electron microscope (FEI Co., Eindhoven, The Netherlands).

Morphological analysis of apoptosis by Hoechst 33258 labeling. To analyze the apoptotic morphology by fluorescence microscopy, both control and BSAO/Spm-treated melanocytes and melanoma cells, grown on coverslips, were fixed with $3.7 \%$ paraformaldehyde in PBS for $10 \mathrm{~min}$ at room temperature. Then, samples were labeled with Hoechst 33258 at the concentration of $0.1 \mu \mathrm{g} / \mathrm{ml}$ for $15 \mathrm{~min}$ to counterstain DNA and observed with a CCD camera equipped light microscope Olympus BX51 (Olympus, Tokyo, Japan).

Flow cytometry analyses. All flow cytometric analyses were carried out on cell suspensions $\left(\sim 10^{6}\right.$ cells $\left./ \mathrm{ml}\right)$ obtained by incubating monolayer cell cultures with EDTA. The fluorescent signals were analyzed by a BDLSRII flow cytometer (Becton-Dickinson, Mountain View, CA) equipped with a $5 \mathrm{~mW}, 488 \mathrm{~nm}$, air-cooled argon ion laser and a Kimmon $\mathrm{HeCd} 325 \mathrm{~nm}$ laser. The fluorescence emissions were collected through a 530-nm band pass filter for fluorescein isothiocyanate conjugated antibody (FITC), a 575-nm band pass filter for propidium iodide (PI). At least 10,000 events/sample were acquired in linear for cell cycle studies or log mode for Annexin V-FITC labeling. Percentages of cells in subG1, G1, $\mathrm{S}$ and $\mathrm{G} 2 / \mathrm{M}$ phases of cell cycle and percentages of early and late apoptotic cells were calculated using the FACS Diva Software (Becton-Dickinson).

Determination of apoptotic cell death by Annexin V-FITC staining. To detect phosphatidylserine translocated from the inner face to the outer surface of plasma membrane in the initial step of apoptosis, an Annexin V-FITC apoptosis detection kit (MBL, Medical and Biological Laboratories Co., Ltd., Japan) was used as described by Van Engeland et al (19). About 50 phosphatidylserine monomers are estimated to be bound per each Annexin V molecule. M14 WT and M14 ADR2 cells $\left(1 \times 10^{6} / \mathrm{ml}\right)$ were treated with $50 \mu \mathrm{M}$ CQ for $24 \mathrm{~h}$ or with BSAO $\left(6.5 \times 10^{-3} \mathrm{IU} / \mathrm{ml}\right)$ and spermine $(6 \mu \mathrm{M})$ for $1 \mathrm{~h}$ at $37^{\circ} \mathrm{C}$ or with the combination $\mathrm{CQ}$ and $\mathrm{BSAO} /$ spermine. Cell suspensions were then plated in tissue culture-coated Petri dishes containing culture medium supplemented with FBS. After incubation at $37^{\circ} \mathrm{C}$ for 48 and $72 \mathrm{~h}$, cells were detached, centrifuged and resuspended in binding buffer (10 mM HEPES/NaOH, $\mathrm{pH} 7.5$, $140 \mathrm{mM} \mathrm{NaCl}$ and $\left.2.5 \mathrm{mM} \mathrm{CaCl}{ }_{2}\right)$. Cell suspension $\left(\sim 5 \times 10^{5}\right)$ was then incubated with $1 \mu \mathrm{g} / \mathrm{ml}$ of Annexin V-FITC and with $1 \mu \mathrm{g} / \mathrm{ml}$ of PI for $10 \mathrm{~min}$ at room temperature in the dark. The populations of Annexin V-FITC negative/PI negative cells (viable cells), Annexin V-FITC positive/PI negative cells (early apoptosis) and Annexin V-FITC positive/PI positive cells (late apoptosis) were evaluated by flow cytometry (19). The dot plots reported in Fig. 2 were obtained from one out of three independent experiments which gave very comparable results. 
Cell cycle analysis. Cell cycle distribution was analyzed by labelling cells with PI. Assays were carried out as described by Nicoletti et al (20). M14 WT and ADR2 cells $\left(1 \times 10^{6} / \mathrm{ml}\right)$, obtained from different treatments, as described in Annexin V-FITC labeling, were collected, washed twice with cold PBS and then centrifuged. The pellet was fixed in $70 \%$ ethanol in PBS at $4^{\circ} \mathrm{C}$ for $1 \mathrm{~h}$, washed twice and then re-suspended in PBS containing $100 \mu \mathrm{g} / \mathrm{ml}$ Ribonuclease A (RNAse) and $40 \mu \mathrm{g} / \mathrm{ml}$ PI. After incubation at $37^{\circ} \mathrm{C}$ for $30 \mathrm{~min}$, cells were analyzed by flow cytometry.

Confocal microscopy observations of acidic vacuoles. To analyze by laser scanning confocal microscopy (LSCM) the formation of acidic vacuoles in M14 cells, induced by treatment with $50 \mu \mathrm{M} \mathrm{CQ}$, the vital staining with acridine orange solution was performed. Cells were grown on the coverslips until confluent state and then treated with the lysosomotropic compound for $24 \mathrm{~h}$. The cells were incubated with acridine orange solution $(2.5 \mu \mathrm{g} / \mathrm{ml})$ for $15 \mathrm{~min}$ at $37^{\circ} \mathrm{C}$; after $20 \mathrm{~min}$ in drug-free medium at $37^{\circ} \mathrm{C}$, then washed with PBS and immediately observed. The observations of acidic vacuoles were carried out using a Leica TCS SP2 spectral confocal microscope (Leica Microsystems, Wetzlar, Germany) equipped with Argon-Helium-Neon lasers. In these organelles, the stacked form of acridine orange generates a bright red fluorescence; on the contrary in the nucleus and cytoplasm, unstacked acridine orange displays variable green fluorescence.

Statistical analysis. Values reported in the figures are means \pm standard deviation (SD) from 3-6 independent experiments. Statistical analyses were performed using Student's $\mathrm{t}$-test, with $\mathrm{p}<0.05$ considered statistically significant.

\section{Results}

Enhancement of the cytotoxic effect of polyamine metabolites by pre-incubation with chloroquine. Cloning efficiency test demonstrated that the lysosomotropic compound chloroquine (CQ) was able to increase the cytotoxic activity of BSAO/Spm enzymatic system on both drug sensitive and drug resistant melanoma cells (Fig. 1). Since treatment with $50 \mu \mathrm{M}$ CQ alone for $24 \mathrm{~h}$ did not impair the survival of both cell lines, this subcytotoxic concentration was chosen to sensitize cells to enzymatic products of $\mathrm{BSAO} / \mathrm{Spm}$.

When M14 WT cells were pre-incubated with $50 \mu \mathrm{M}$ $\mathrm{CQ}$ for $24 \mathrm{~h}$ and then exposed for up to $60 \mathrm{~min}$ to BSAO $\left(6.5 \times 10^{-3} \mathrm{IU} / \mathrm{ml}\right)$ and $\mathrm{Spm}(6 \mu \mathrm{M})$ at $37^{\circ} \mathrm{C}$, cell survival percentage significantly decreased, when compared with that of cultures treated with the enzymatic system $\mathrm{BSAO} / \mathrm{Spm}$ alone. The chemosensitizing effect exerted by CQ was much more evident on the MDR melanoma cell line, whose cell survival decreased to about $10 \%$ after $60 \mathrm{~min}$ of $\mathrm{BSAO} / \mathrm{Spm}$ treatment (Fig. 1).

Induction of apoptotic cell death by treatment with the combination $C Q+B S A O / S p m$. The induction of apoptosis was analyzed by flow cytometry at 48 and $72 \mathrm{~h}$ after the end of the treatment (Fig. 2) on control and treated cells labelled with Annexin V-FITC and PI. According to clonogenic data, the treatment with $\mathrm{CQ}$ alone did not change the fraction of

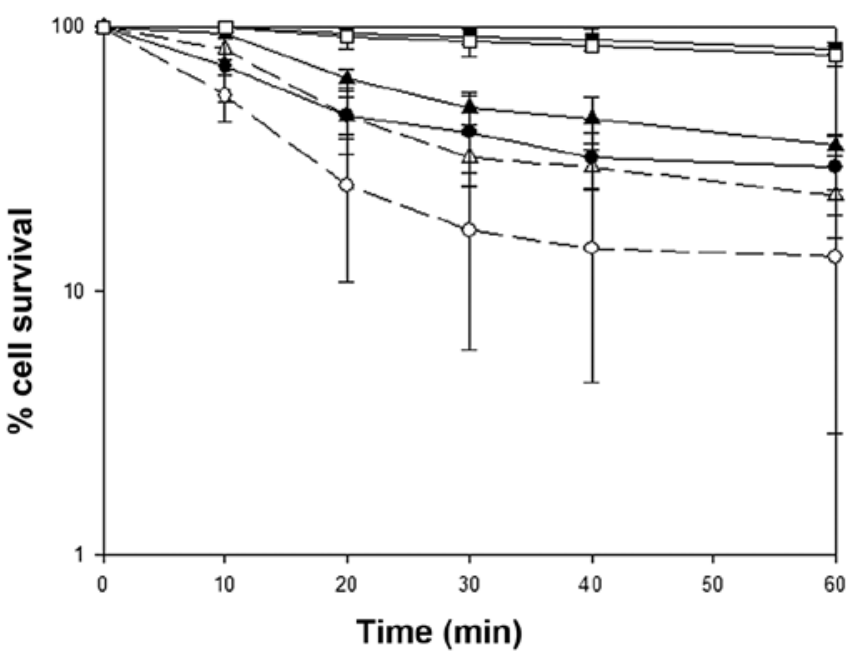

Figure 1. Effect of pre-incubation with $50 \mu \mathrm{M}$ CQ on the sensitivity of M14 melanoma cells to cytotoxic polyamine metabolites. M14 WT and M14 ADR2 cells ( $\triangle$, O open symbols) were pre-treated at $37^{\circ} \mathrm{C}$ with $50 \mu \mathrm{M}$ CQ alone, for $24 \mathrm{~h}$. After pre-incubation cells were washed and then exposed to BSAO $\left(6.5 \times 10^{-3} \mathrm{IU} / \mathrm{ml}\right)$ and spermine $(6 \mu \mathrm{M})$, at $37^{\circ} \mathrm{C}$ up to $60 \mathrm{~min}$, followed by the plating efficiency. Cell survival was compared with cells only incubated with $\operatorname{BSAO}\left(6.5 \times 10^{-3} \mathrm{IU} / \mathrm{ml}\right)$ and spermine $(6 \mu \mathrm{M})(\boldsymbol{\wedge}, \bullet$ dark symbols $)$ and with control cells WT, ( $\square$ dark symbol) and ADR2 ( $\square$ open symbol) treated with $\mathrm{CQ}$ alone. Means $\pm \mathrm{SD}$ are shown for three to six estimations for four to six experiments. Where not shown, SDs lie within the symbols. See the text for details of the curves.

early and late apoptotic cells in comparison with the untreated cells. The treatment with $\mathrm{BSAO} / \mathrm{Spm}$ alone induced a slight increase of early (8.0 and $11.9 \%)$ and late (7.0 and 5.1\%) apoptotic cells on M14 WT and ADR2 cells, respectively. These percentages significantly increased after pre-incubation with CQ (9.7 and $32.7 \%$ for the early fraction, and 11.2 and $11.4 \%$ for the late fraction on M14 WT and ADR2 cells, respectively). The apoptotic effect was clearly more evident in drug resistant M14 cells, and after $72 \mathrm{~h}$ from the end of the combined treatment. In fact, at this time, pre-treatment with CQ significantly increased the percentage of apoptotic cells (63.9\%) in drug resistant melanoma cultures compared to that determined in the sensitive ones (27.6\%).

The analysis of the cell cycle (Fig. 3) confirmed the data obtained by Annexin V-FITC/PI test. The treatment with CQ alone did not change the percentage of subG1, G1, S and G2/M fractions on either cell line. The treatment with BSAO/Spm induced a slight increase of subG1 cell fraction on M14 WT cells $(19.0 \%)$ and a more significant increase on M14 ADR2 cells (24.4\%). When M14 WT cells were incubated for $24 \mathrm{~h}$ with CQ and then treated with $\mathrm{BSAO} / \mathrm{Spm}$ a remarkable increase of the subG1 cell fraction was revealed (27.3\%). This effect was much more evident on M14 ADR2, where the subG1 fraction reached the value of $44.2 \%$.

Confocal microscopy observations of the lysosomotropic effect induced by $C Q$. The treatment with $50 \mu \mathrm{M}$ CQ for $24 \mathrm{~h}$ induced an increase of the acidic compartments in drug sensitive and resistant melanoma cells, as demonstrated by the staining with the acridine orange solution and observations by LSCM of vital cells. In control M14 WT (Fig. 4A) and M14 ADR2 cells (Fig. 4B) the red signal appeared localized in 
A

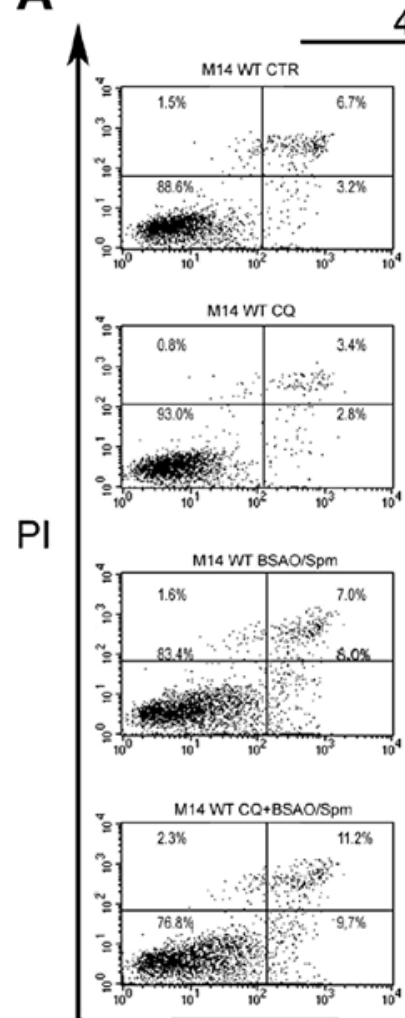

$48 \mathrm{~h}$
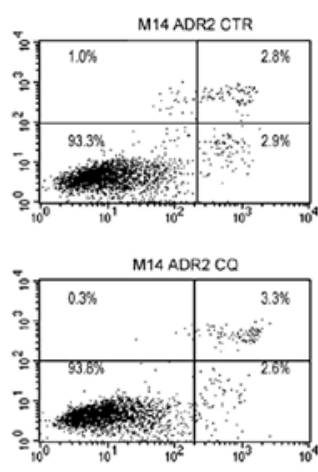

M14 ADR2 BSAO/Spm
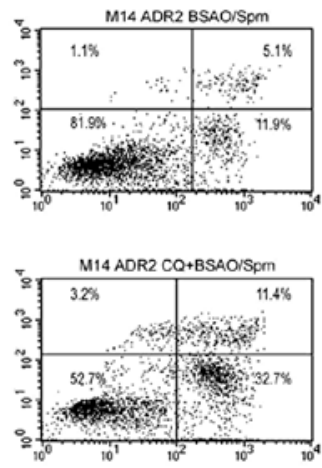

B
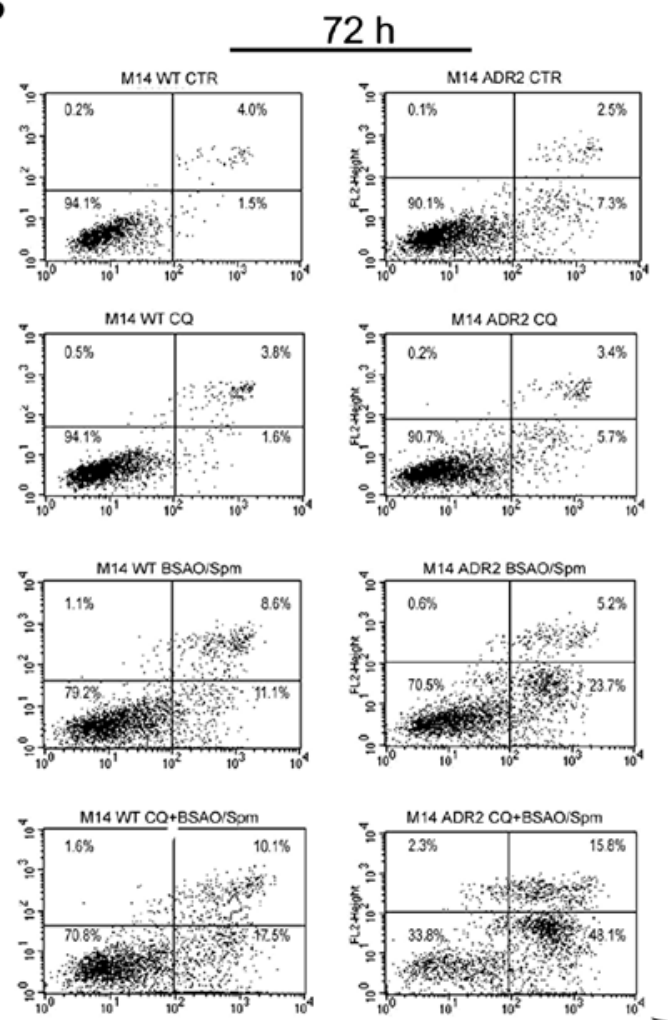

Annexin V-FITC

Figure 2. Flow cytometric analysis of apoptosis performed on M14 WT and M14 ADR2 cells by double labelling with Annexin V-FITC and PI at 48 h (left panels) and $72 \mathrm{~h}$ (right panels) after the end of the treatment. The analysis was carried out on: untreated melanoma cells (CTR); cells exposed to $50 \mu \mathrm{M}$ CQ for $24 \mathrm{~h}$; cells treated for $60 \mathrm{~min}$ with $6.5 \times 10^{-3} \mathrm{IU} / \mathrm{ml} \mathrm{BSAO}$ and $6 \mu \mathrm{M}$ spermine; cells exposed for $24 \mathrm{~h}$ to $50 \mu \mathrm{M} \mathrm{CQ}$ and then treated for $60 \mathrm{~min}$ with $6.5 \mathrm{x} .10^{-3} \mathrm{IU} /$ $\mathrm{ml} \mathrm{BSAO}$ and $6 \mu \mathrm{M}$ spermine. The figure shows dot plots obtained from one out of three experiments, performed in the same experimental conditions, which gave very similar results. See Results section for a more detailed description.

A

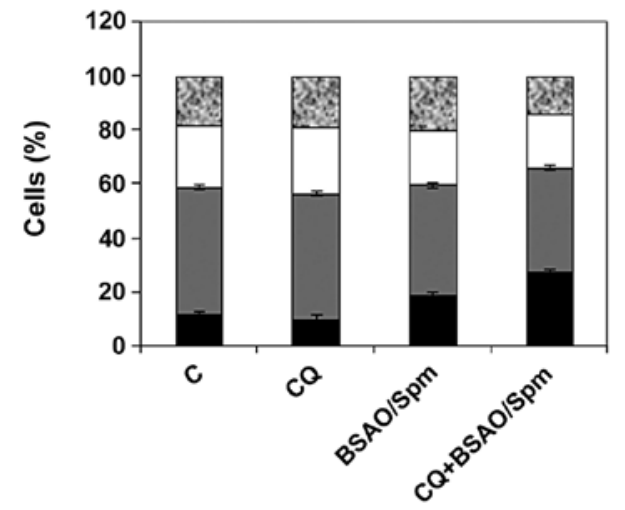

$\begin{array}{ll}\text { G2/M } & \square \text { G1 } \\ \mathrm{S} & \square \text { subG1 }\end{array}$
B

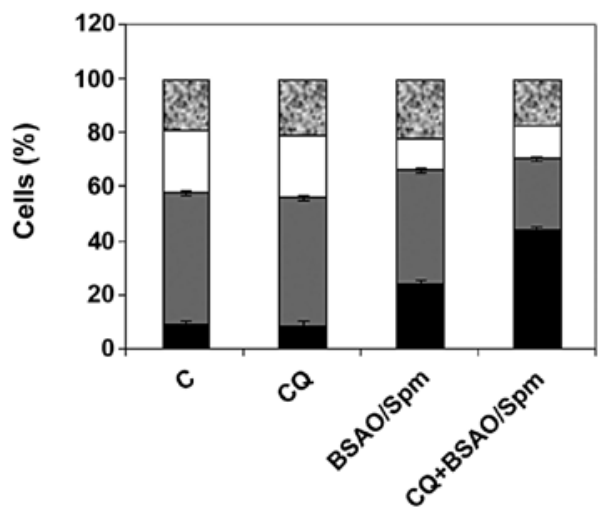

Figure 3. Cell cycle analysis carried out by flow cytometry on M14 melanoma cells. M14 WT (A) and M14 ADR2 (B) cells have been treated as for the apoptosis detection (Fig. 2). The values of the percentages of cells in subG1, G1, S and G2/M phases of cell cycle, calculated by FACS DIVA software, are the mean \pm standard deviation from three independent experiments.

cytoplasmic perinuclear organelles that noticeably increased in number after the treatment with CQ in both sensitive and resistant cells (Fig. 4C and D, respectively), suggesting the induction of a lysosomotropic effect. 

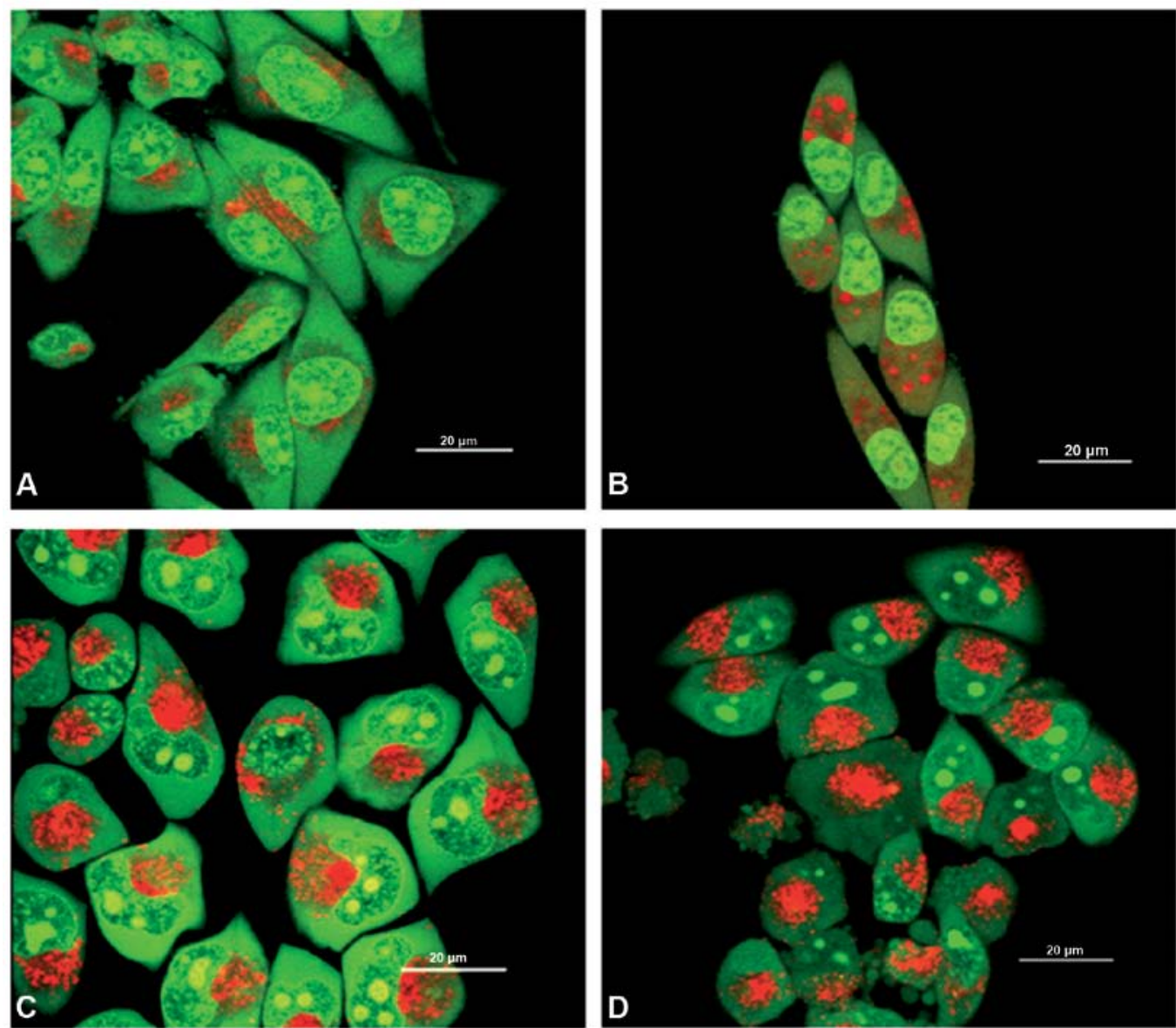

Figure 4. Effect of CQ treatment on the intracellular distribution of acridine orange-positive structures in M14 melanoma cells observed by confocal microscopy. In control M14 WT (A) and M14 ADR2 (B) cells the red signal appeared to be localized in cytoplasmic perinuclear vesicles. The treatment with $50 \mu \mathrm{M} \mathrm{CQ}$ for $24 \mathrm{~h}$ induced the increase of the acidic compartments in both drug sensitive (C) and resistant melanoma cells (D), confirming the induction of a lysosomotropic effect.

Ultrastructural alterations induced by the combined treatment with $C Q+B S A O / S p m$. Transmission electron microscopy observations on ultrathin sectioned melanoma cells allowed the detection of the subcellular changes related to the potency of the cytotoxic effect of $\mathrm{BSAO} / \mathrm{Spm}$ exerted by CQ pre-treatment (Fig. 5). According to the above reported observations, the treatment with CQ alone did not induce any evident alteration of the subcellular structures, either on sensitive or resistant cells (Fig. 5B and F, respectively), which appeared to be well preserved as in the corresponding control untreated cells (Fig. 5A and E, respectively). However, after CQ treatment the appearance of a large number of lysosomes and cytoplasmic vacuoles were observed. After incubation with BSAO/Spm enzymatic system, M14 WT cells did not show significant ultrastructural modifications (Fig. 5C), according to previous reported observations by Agostinelli et al (9). On the contrary, the mitochondria of M14 ADR2 cells showed rarefied matrix and swollen cristae (Fig. 5G). Finally, in both melanoma cell lines treated for $24 \mathrm{~h}$ with CQ and then with $\mathrm{BSAO} / \mathrm{Spm}$, numerous lysosomes and cytoplasmic vacuoles were still observable inside most cells (Fig. 5D and H, respectively). Moreover, the mitochondria of cells treated with the combination $\mathrm{CQ}+\mathrm{BSAO} / \mathrm{Spm}$ showed alterations much more evident than those present in cells treated with $\mathrm{BSAO} / \mathrm{Spm}$ alone. Again, M14 ADR2 cells were more susceptible than M14 WT cells to the enzymatic oxidation products of BSAO/ Spm system.

Effects of BSAO/Spm enzymatic system, acrolein and hydrogen peroxide on the cell survival of melanoma cells and melanocytes. On the basis of the above reported results demonstrating that the enzymatic oxidation products of BSAO/Spermine system induce cytotoxic effect on cultured melanoma cells and in order to exclude undesirable side-effects in view of clinical applications, we then analyzed by MTT test the possible cytotoxic effect of the enzymatic system on human melanocytes. The results of the cytotoxicity test, besides confirming that melanoma resistant cells (M14 ADR2) are more sensitive than their wild-type counterparts (M14 WT) to the BSAO/ Spm treatment, and showed that melanocytes display a greater resistance than melanoma cells against the treatment with the enzymatic system, up to $60 \mu \mathrm{M}$ spermine concentration for $1 \mathrm{~h}$ (Fig. 6 insert). In particular, after treatment with $9 \mu \mathrm{M}$ spermine $>90 \%$ of melanocytes were viable.

Fig. 6 also shows the comparison between melanocytes and melanoma cells regarding their survival after treatment with $\mathrm{BSAO} / \mathrm{Spm}$ alone or with the combined treatment $\mathrm{CQ}+\mathrm{BSAO} / \mathrm{Spm}$. The time course for $60 \mathrm{~min}$ clearly shows 

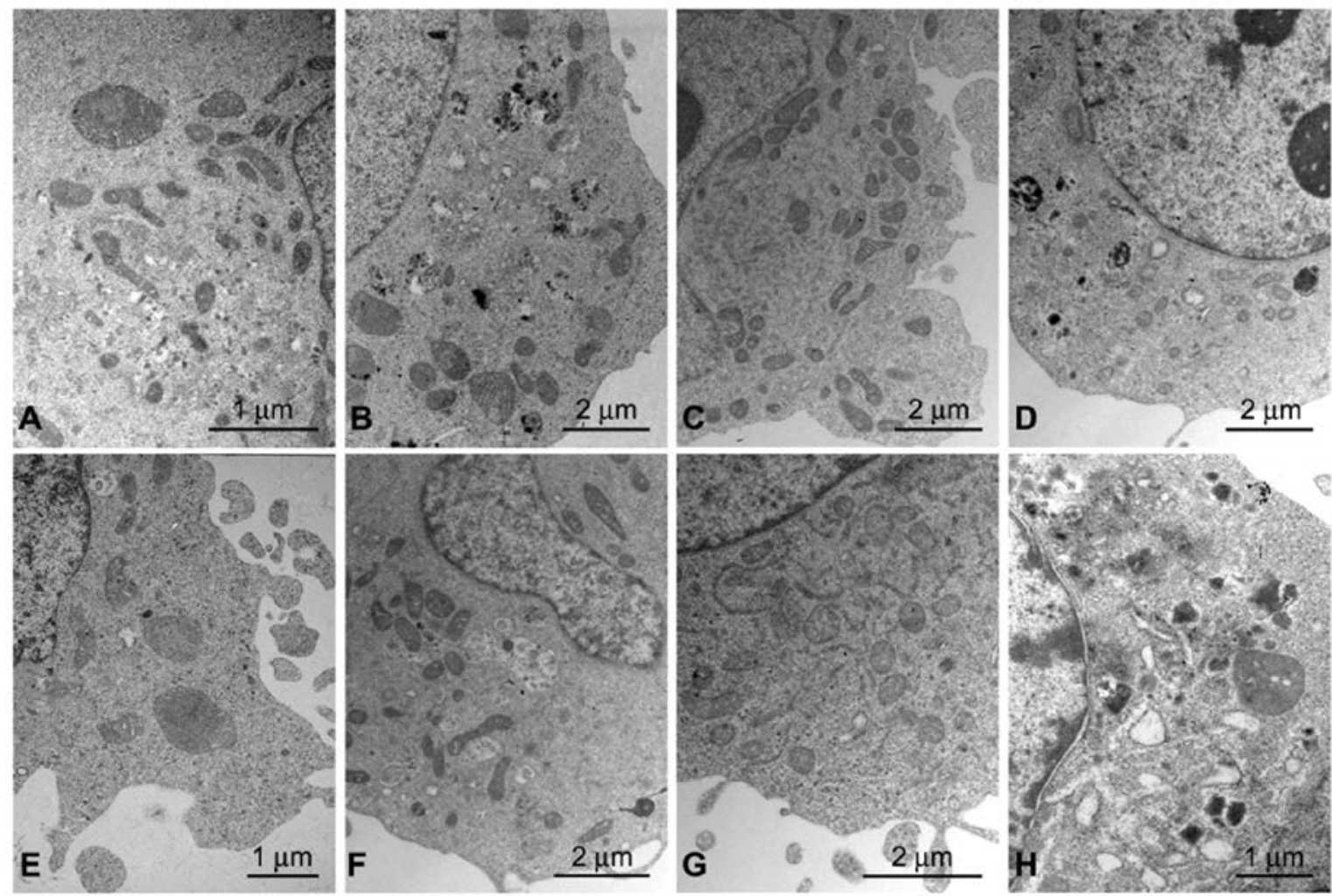

Figure 5. Subcellular changes induced by CQ and BSAO/Spm, given alone or in association, detected by transmission electron microscopy observations. The treatment with CQ alone did not induce any evident alteration of the subcellular structures, either on sensitive (B) or resistant (F) cells which appeared to be well preserved as the corresponding control cells (A and E); however, after CQ treatment the appearance of a large number of lysosomes and cytoplasmic vacuoles were observed. After incubation with BSAO/Spm alone, M14 WT cells did not show significant ultrastructural modifications (C) whereas the mitochondria of M14 ADR2 cells showed rarefied matrix and swollen cristae (G). In both melanoma cell lines treated for $24 \mathrm{~h}$ with CQ and then with BSAO/Spm $(\mathrm{D}$ and $\mathrm{H})$, the subcellular alterations were much more evident than those present in cells treated with BSAO/Spm alone, particularly in M14 ADR2 cells.
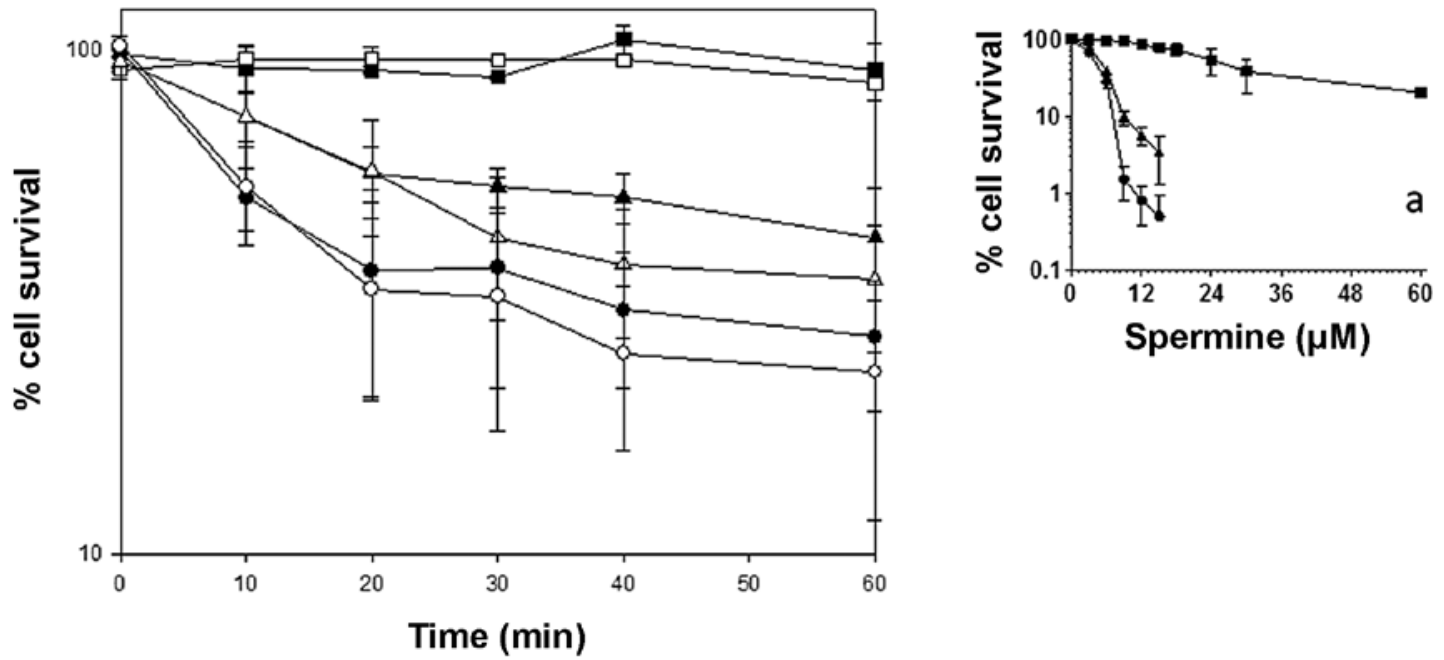

Figure 6. Effect of pre-incubation with $15 \mu \mathrm{M} \mathrm{CQ}$ on the sensitivity of M14 melanoma cells and melanocytes to cytotoxic polyamine metabolites. M14 WT, M14 ADR2 cells and melanocytes ( $\triangle, \circ, \square$ open symbols) were pre-incubated with $15 \mu \mathrm{M}$ CQ alone for $24 \mathrm{~h}$ and then washed and treated with BSAO $\left(6.5 \times 10^{-3} \mathrm{IU} / \mathrm{ml}\right)$ and spermine $6 \mu \mathrm{M}$, up to $60 \mathrm{~min}$. The cell survival was compared with M14 WT, M14 ADR2 cells and melanocytes $(\boldsymbol{\Lambda}, \bullet, \bullet$ dark symbols $)$ that were only incubated with BSAO $\left(6.5 \times 10^{-3} \mathrm{IU} / \mathrm{ml}\right)$ and spermine $(6 \mu \mathrm{M})$. The insert (A) shows the percentage of cell survival of M14 WT ( $\left.\mathbf{\Delta}\right)$, M14 ADR2 $(\bullet)$ cells and melanocytes $(\boldsymbol{\square})$ after incubation with $0-60 \mu \mathrm{M}$ spermine and $\left(6.5 \times 10^{-3} \mathrm{IU} / \mathrm{ml}\right) \mathrm{BSAO}$ for $60 \mathrm{~min}$ at $37^{\circ} \mathrm{C}$. Means $\pm \mathrm{SD}$ are shown for three to six estimations for four to six experiments. Where not shown, SDs lie within the symbols.

that melanocytes, differently from melanoma cells, are virtually unaffected by the enzymatic system, even when preceded by CQ treatment.
Moreover, the cytotoxic effects induced by the enzymatic system were compared to those exerted singularly by the two oxidation products, $\mathrm{H}_{2} \mathrm{O}_{2}$ and aldehyde (acrolein) at the same 


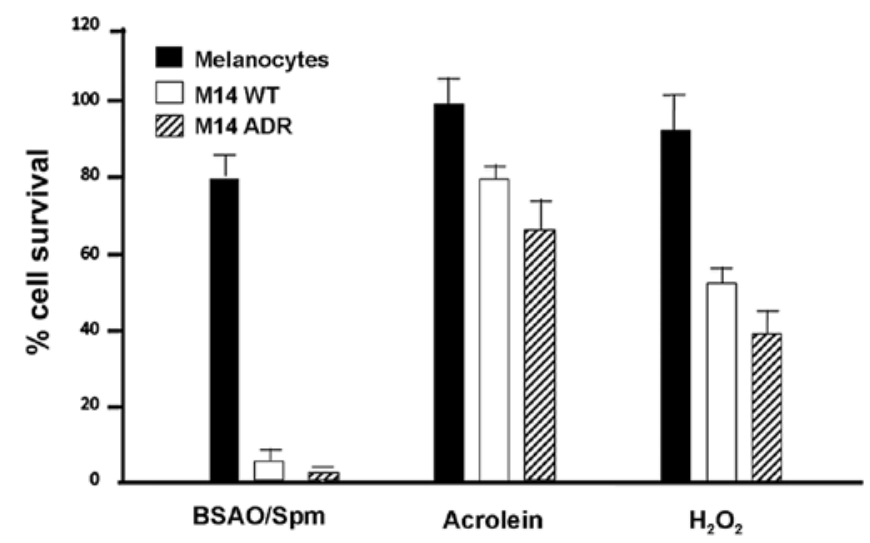

Figure 7. Effect of BSAO/spermine, exogenous hydrogen peroxide and acrolein on M14 melanoma and melanocyte cell viability. M14 WT, M14 ADR2 cells and melanocytes were treated for $60 \mathrm{~min}$ at $37^{\circ} \mathrm{C}$ with $6.5 \times 10^{-3} \mathrm{IU} / \mathrm{ml} \mathrm{BSAO}$ in presence of $12 \mu \mathrm{M}$ spermine, or $12 \mu \mathrm{M}$ exogenous acrolein or exogenous hydrogen peroxide. Subsequently cell viability was determined by MTT. Means \pm SD are shown for three to six estimations for four to six experiments. molar concentration of spermine $(12 \mu \mathrm{M})$, on melanoma cells and melanocytes (Fig. 7). Since acrolein is considered as the potential cytotoxic product of spermine (21), and since it is not known which of the aldehydes is formed preferentially from spermine under the experimental conditions $(8,12)$, acrolein was used as a model compound. Exogenous acrolein administered alone for $60 \mathrm{~min}$ induced low cytotoxicity on melanoma cells and, noteworthy, it was completely ineffective against melanocytes. Conversely, at the same concentration and incubation time, exogenous $\mathrm{H}_{2} \mathrm{O}_{2}$ caused a light effect on melanocytes and noticeable cytotoxicity on melanoma cells.

Morphological and ultrastructural modifications induced by enzymatic system on melanoma cells and melanocytes. The evaluation of the apoptosis induction carried out by fluorescence microscopy after Hoechst 33258 staining confirmed the results obtained by the cytotoxicity test. After treatment with $\mathrm{BSAO} / \mathrm{Spm}$ the nuclei of normal melanocytes (Fig. 8B) appeared to be unaltered when compared to those of control
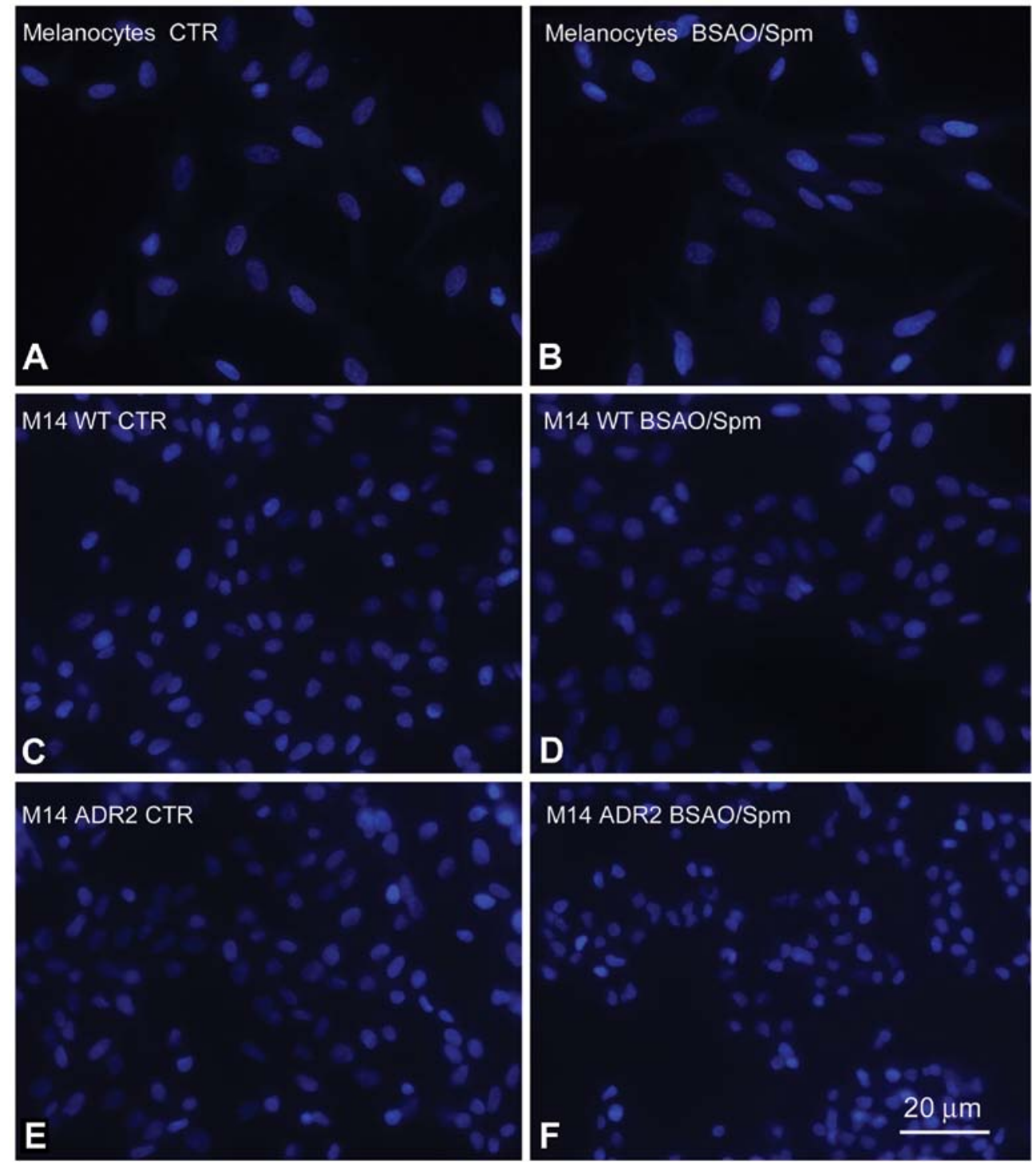

Figure 8. Evaluation of apoptosis induced by treatment with BSAO/Spm on melanocytes and melanoma cells. After staining with Hoechst 33258 , the nuclei of melanocytes treated with $\mathrm{BSAO} / \mathrm{Spm}$ (B) appeared to be unaltered when compared to those of control ones (A). Conversely, after the same treatment numerous apoptotic nuclei were observed in both M14 WT (D) and M14 ADR2 (F) cell cultures, not detectable in the corresponding control cultures (C and E). 

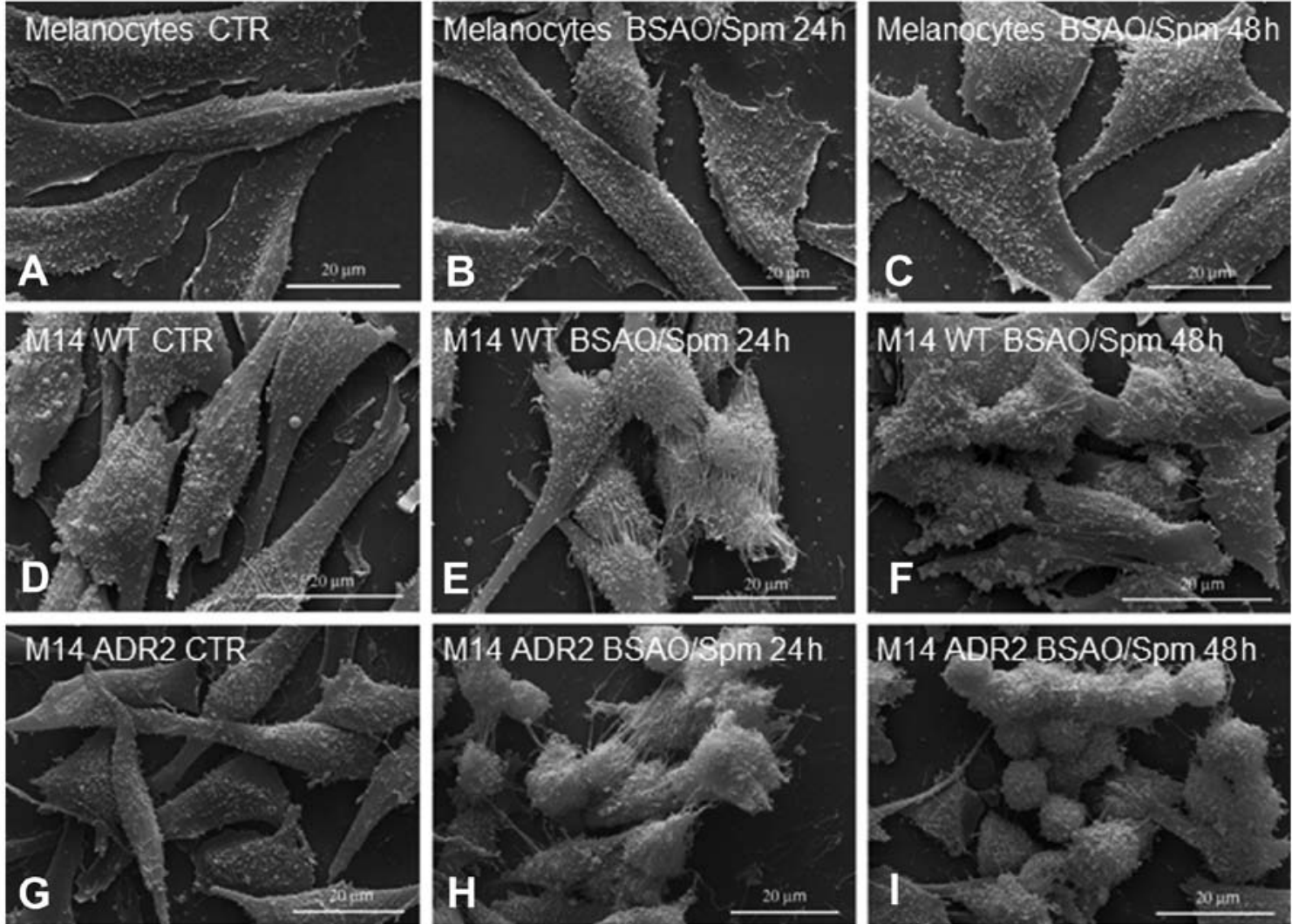

Figure 9. Effects of BSAO/Spm treatment on the morphology of melanoma cells and melanocytes observed by scanning electron microscopy. Control melanocytes (A), M14 WT (D) and M14 ADR2 (G) cells displayed very similar morphology characterized by bipolar elongated shape. After 24 or $48 \mathrm{~h}$ of $\mathrm{BSAO} / \mathrm{Spm}$ treatment (B and C, respectively), melanocytes showed unaltered morphological features. On the contrary, after treatment for $24 \mathrm{~h}$ with the enzymatic system, both sensitive $(\mathrm{E})$ and resistant $(\mathrm{H})$ melanoma cells appeared to be rounded in shape and tended to partially detach from the substrate. Such alterations were even more evident after treatment for $48 \mathrm{~h}$ and more dramatic on M14 ADR2 cells (I) than in the sensitive counterparts (F).

ones (Fig. 8A). Conversely, after the same treatment numerous apoptotic nuclei were observed in both M14 WT and M14 ADR2 cell cultures (Fig. 8D and F, respectively), while they were not detectable in the corresponding control cultures (Fig. 8C and E).

The effects of BSAO/Spm treatment on the morphology of melanoma cells and melanocytes were also analyzed by scanning electron microscopy (Fig. 9). Control melanocytes (Fig. 9A), M14 WT (Fig. 9D) and M14 ADR2 (Fig. 9G) cells displayed very similar morphology characterized by bipolar elongated shape and the cell surface covered by short and randomly dispersed microvilli. Accordingly to cytotoxicity data, melanocytes showed unaltered morphological appearance either after 24 or $48 \mathrm{~h}$ of BSAO/Spm treatment (Fig. 9B and $\mathrm{C}$, respectively). On the contrary, after treatment for $24 \mathrm{~h}$ both sensitive (Fig. 9E) and resistant (Fig. 9H) melanoma cells appeared to be rounded in shape and tended to partially detach from the substrate. Moreover, numerous thin and long cell protrusions connecting adjacent cells were easily detectable. Such alterations were even more evident after treatment for $48 \mathrm{~h}$ and more dramatic on M14 ADR2 cells (Fig. 9I) than in the sensitive counterparts (Fig. 9F).

Transmission electron microscopy observations of ultrathin sectioned cells substantially confirmed the scarce susceptibility of melanocytes to BSAO/Spm treatment (Fig. 10). In fact, melanocytes treated with spermine
(Fig. 10B) at the concentration $(6 \mu \mathrm{M})$ that induces cytotoxicity in melanoma cells, displayed an unaltered ultrastructural appearance when compared to untreated cells (Fig. 10A). In particular, mitochondria, the main subcellular target of the oxidation products of the enzymatic system (22), maintained the orthodox feature, characterized by regular shape and parallel cristae. To induce light intracristal swelling and matrix rarefaction in melanocyte mitochondria, 10 times higher concentration of spermine $(60 \mu \mathrm{M})$ had to be administered (Fig. 10C).

As expected, many treated melanoma cells observed by transmission electron microscopy showed the typical apoptotic changes consisting in evident alterations of the cytoplasmic organelles and chromatin condensation and marginalization. Fig. 10D shows an apoptotic melanoma cell treated with $\mathrm{BSAO} / \mathrm{Spm}(6 \mu \mathrm{M})$.

\section{Discussion}

In conventional cancer chemotherapy, numerous obstacles exist preventing successful treatment, such as the poor selectivity of the cytotoxic drugs for tumours and the development of MDR of cancer cells, which represent the most difficult problems to solve. Therefore, alternative therapeutic strategies are required. Among these, although still at a beginning, enzymatically formed ROS have certain potential 

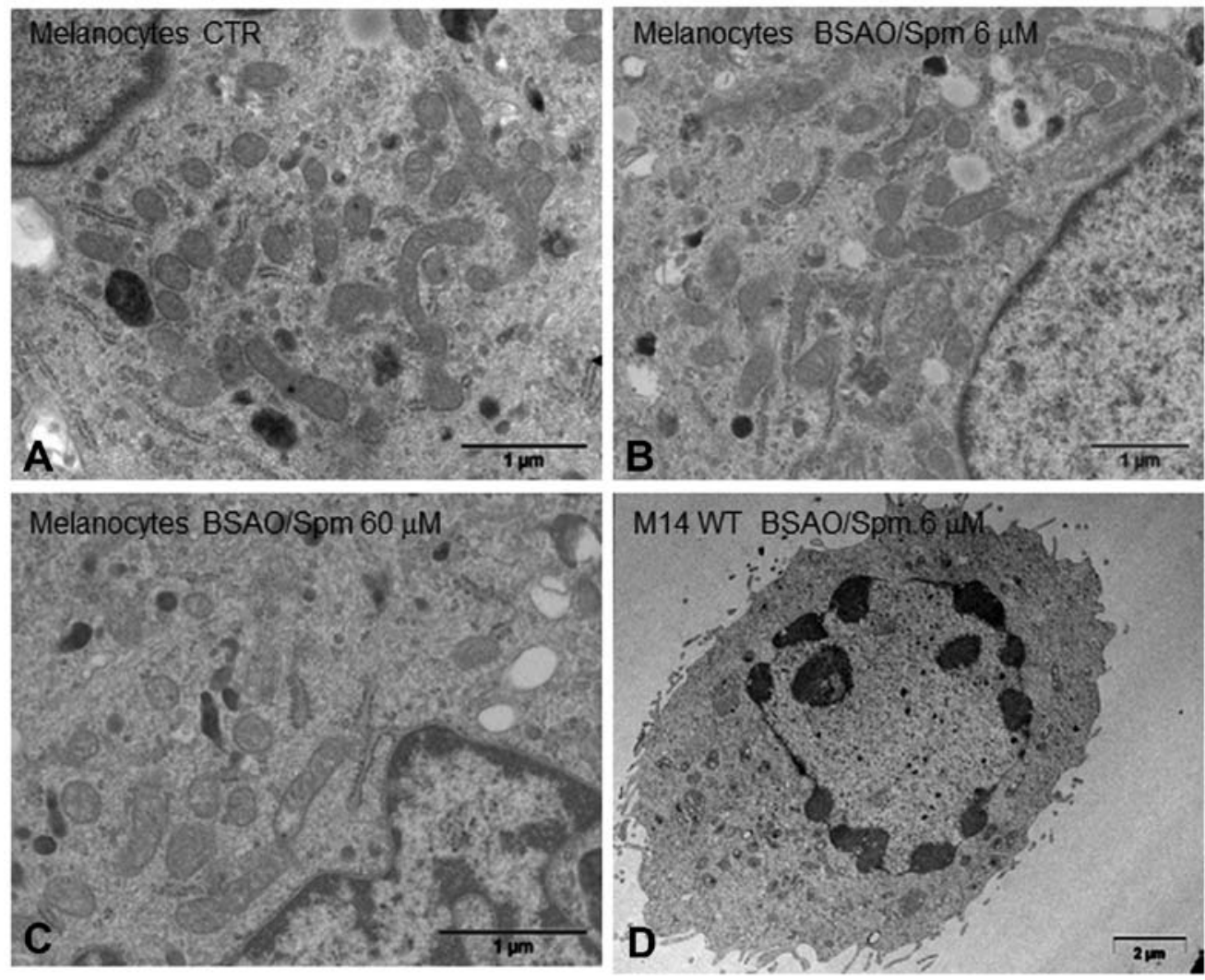

Figure 10. Transmission electron microscopy observations of melanocytes treated with BSAO/Spm. Melanocytes treated with BSAO and $6 \mu \mathrm{M}$ spermine (B) displayed unaltered ultrastructural appearance when compared to control untreated melanocytes (A). In particular, mitochondria, the main subcellular target of the oxidation products of the enzymatic system, maintained their typical structure. Only very high concentration of spermine $(60 \mu \mathrm{M})$ was able to induce light cristal swelling and matrix rarefaction (C). As comparison, the micrograph (D) shows an M14 WT melanoma cell treated with BSAO/Spm (6 $\mu \mathrm{M})$ which underwent the typical apoptotic changes consisting in evident alterations of the cytoplasmic organelles and chromatin condensation.

in cancer therapy. The in situ formation of toxic compounds or radicals by enzyme-catalyzed reactions is a promising start $(5,23,24)$. In previous papers we reported on investigations on the potential use, as antitumour agent, of an enzyme capable of forming cytotoxic products (hydrogen peroxide and aldehydes) from polyamines that are present at elevated levels in cancer cells. In vitro studies were carried out on Chinese hamster ovary (CHO) cells (25), and human colon adenocarcinoma cells (12) as well as on human melanoma (M14) (8) and mouse melanoma tumour cells (B16-F0) (26). It was observed that hydrogen peroxide and aldehydes, enzymatic oxidation products of polyamines, exerted greater cytotoxic effects on colchicine- and doxorubicin-resistant cells (CHO-CHC5 and LoVo DX, respectively) than on their parental sensitive counterparts (CHO-AuxB1 and LoVo WT) $(22,27)$. The growth of the mouse melanoma was inhibited by exposure to BSAO and spermine $(26,28)$ and for the slow release of toxic enzymatic oxidation products of spermine into the tumour, the use of BSAO conjugated to biocompatible polymers was considered $(28,29)$. However, in the case of BSAO, the administration of the substrate spermine, might be unnecessary in a new therapeutic approach, since cancer cells have high polyamine concentrations $(5,6,30)$, and the polyamines are released into the cellular environment, if cells are damaged (23). Therefore, the aim of the present study was to further improve our knowledge of polyaminederived cytotoxic products in causing cell death.
From a therapeutic point of view, the improvement of the efficacy of in situ formation of the cytotoxic oxidation products of spermine is fundamental. This may be pursued by the combined treatment with lysosomotropic compounds that might improve cell damage caused by spermine metabolites. In this study, emphasis was put on the ability of CQ to sensitize melanoma cells to the cytotoxic effect induced by $\mathrm{H}_{2} \mathrm{O}_{2}$ and aldehyde, formed from BSAO/spermine enzymatic system (22).

Cell survival experiments were carried out on WT and MDR melanoma cells (M14). As previously observed by using the lysosomotropic compound MDL 72527 (8), shorter survival was observed in both cell lines after pre-incubation with CQ (50 $\mu \mathrm{M}$ for $24 \mathrm{~h}$ ) before the subsequent exposure to spermine metabolites. The sensitization began at low concentration $(10 \mu \mathrm{M})$ but was more evident at $50 \mu \mathrm{M} \mathrm{CQ}$. Cytotoxicity was significantly greater on cells treated with the combined treatment than on those treated with $\mathrm{BSAO} /$ spermine alone, even though CQ alone did not reduce the number of viable cells under the experimental conditions. However, an impairment of cell metabolism by CQ was indicated by an increase of the number of lysosomes. The treatment with $50 \mu \mathrm{M}$ CQ for $24 \mathrm{~h}$ induced an enhancement of the acidic compartments in both drug sensitive and resistant melanoma cells, as demonstrated by the staining with the acridine orange solution and observations by LSCM of vital cells, hypothesizing the induction of a lysosomotropic effect. 
Interestingly, the test of cytotoxicity showed that melanocytes display a higher resistance than melanoma cells against the treatment with the enzymatic system. In fact, more than $90 \%$ of melanocytes were viable after treatment with $9 \mu \mathrm{M}$ spermine. Moreover, an interesting result was obtained when melanocytes were treated with CQ alone or in combination with $\mathrm{BSAO} /$ spermine. Melanocytes, differently from melanoma cells, were unaffected by the enzymatic system, even when preceded by CQ treatment (Fig. 6). This phenomenon could be due to the higher reactivity of the cellular defense systems in melanocytes than in melanoma cells. It was reported that CQ induced cell death dependent on GSH depletion in human glioblastoma cells (31) and cell growth inhibition, cell cycle arrest and apoptosis on breast cancer cells (32). In addition, it was suggested that autophagy, a lysosomal degradation pathway, is necessary for anti-immune responses. In response to chemotherapy, autophagy in dying cancer cells enables the release of ATP, which attracts immune cells and triggers an anti-immune response $(33,34)$.

In addition to its anticancer effects $(31,32), C Q$ is a well known lysosomotropic compound $(35,36)$, because it accumulates in lysosomes, increasing their volume, causing permeability and release of lysosomial enzymes. Its lysosomotropic properties are probably responsible for several of the biological effects of this drug. Among these, CQ can sensitize cancer cells to the cytotoxic effects of chemotherapeutic agents, mainly due to modulating effect on $\mathrm{ABC}$ transporters by inhibiting the drug efflux mediated by $\mathrm{ABC}$ proteins (37). Therefore, its application as an effective sensitizer in cancer therapies could be a promising new therapeutic strategy (38). The cancer-specific chemosensitizer effect of CQ may be partly dependent on its ability to inhibit autophagy $(35,36,38)$. However, whereas other autophagy inhibitors, such as 3-methyladenine, inhibit autophagy in its early phase, consequently resulting in inhibition of the formation of acidic vesicular organelles, as autophagosomes and autolysosomes, CQ inhibits autophagy in its late phase, when autophagosomes have been formed. Moreover, in the cytoplasm of CQ-treated cells, accumulation of acidic vesicular organelles has been reported by Tasdemir et al (36). So, mechanistically, CQ seems to exert its effects through the weak-base lysosomotropic feature $(39,40)$. This drug prevents lysosome acidification, which is not specific to autophagy, but may have other potentially beneficial antitumour effects in addition to autophagy inhibition. For this reason, inhibition of autophagy could be a promising new strategy to improve cancer treatment.

The ultrastructural alterations observed by transmission electron microscopy in the present study (Fig. 6) are evidence in favour of the lysosomotropic properties of CQ. The modifications observed after exposure of M14 cells, both sensitive and resistant, to CQ alone or in combination with BSAO and spermine, are similar to those previously observed in LoVo and M14 cells after treatment with MDL $72527(8,9,12,41)$. The finding support the view that CQ acts as a lysosomotropic compound and that the sensitization of melanoma cells to the treatment with BSAO and spermine is mainly due to the effects induced by $\mathrm{CQ}$ on the endosomal-lysosomal system. Among the ultrastructural changes produced by $\mathrm{CQ}$, the enhancement of lysosomes and the rapid formation of cytoplasmic vacuoles were the most striking. A major role of lysosomes in cell death is presently not doubted (42), and it is known that the release of lysosomal enzymes causes oxidative stress $(43,44)$. The amplification of oxidative stress by the subsequent exposure of cells to hydrogen peroxide, and the toxic effects of the highly reactive spermine-derived aldehydes, explains the increase of cytotoxicity observed in cell survival experiments, in both M14 WT and M14 ADR2 cells. According to Zdolsek et al (45), even the cytotoxicity of hydrogen peroxide is linked with the damage of lysosomal membranes. This observation may be considered as an additional argument in favour of a major role of lysosomes in the cytotoxicity of spermine-derived metabolites.

Analysis by scanning electron microscopy revealed characteristic morphological changes in M14 melanoma cells treated with BSAO and spermine. In general, the morphological alterations of M14 WT and M14 ADR2 cells reflected the results of the cell survival experiments. We presume that the phenotypic changes (transformation of elongated cells into polygonal and rounded shapes) were the result of the impairment of the cytoskeleton due to reaction with spermine metabolites. Such alterations were more marked after treatment for $48 \mathrm{~h}$ on M14 ADR2 cells than in the WT counterparts. On the contrary, according to cytotoxicity data, melanocytes showed unaltered morphological appearance, even after $48 \mathrm{~h}$ of BSAO/Spm treatment. Severe changes of the mitochondrial structure, such as dilatation of the cristae and disruption of membranes were observed by transmission electron microscopy in M14 cells, mainly in multidrug-resistant phenotype. These observations substantially confirmed the scarce susceptibility of melanocytes to BSAO/Spm exposure. In fact, melanocytes treated with $6 \mu \mathrm{M}$ spermine, that induces cytotoxicity in melanoma cells, displayed an unaltered ultrastructural aspect when compared to untreated cells. To induce light intracristal swelling and matrix rarefaction in melanocyte mitochondria, a concentration of at least $60 \mu \mathrm{M}$ spermine was necessary.

There is an ongoing debate on the question, whether hydrogen peroxide or the spermine-derived aldehydes are the major effectors in causing cytotoxicity. We previously demonstrated that catalase added to the culture medium prevented the loss of about $80 \%$ of cell viability, suggesting that hydrogen peroxide is the most important cytotoxic metabolite of spermine in our experimental setting $(8,9)$. If formed by the glucose oxidase reaction, or added as such to the cell suspension, hydrogen peroxide was cytotoxic at lower concentrations than acrolein (26). So, comparing the cytotoxic effect of $12 \mu \mathrm{M}$ spermine in the presence of BSAO, with that of the same concentrations of exogenous hydrogen peroxide and acrolein, the enzymatically formed spermine metabolites were considerably more toxic, on M14 WT and M14 ADR2 cells, than the individual agents. Interestingly, while the enzymatic system induced low cytotoxicity on melanocytes (approximately 20\%) during $60 \mathrm{~min}$ of incubation, exogenous $12 \mu \mathrm{M}$ acrolein administered alone for 60 min was completely ineffective against melanocytes. Conversely, at the same concentration and incubation time, exogenous $\mathrm{H}_{2} \mathrm{O}_{2}$ caused a light cytotoxic effect on the same cells. These findings suggest that a contribution of the aldehydes on the cytotoxicity induced on melanoma cells is 
clear. According to Sharmin et al (21) acrolein is the actual toxic metabolite of spermine. However, acrolein is formed by spontaneous $\beta$-elimination from the aldehydes generated by BSAO-catalyzed oxidative deamination $(8,12,26)$. The rate of $\beta$-elimination is dependent on environmental conditions, and it is unknown under most experimental settings. In view of our lack of knowledge of the composition of the aldehyde mixture formed from spermine under our experimental conditions, it seemed justified, as reported in the Results section, to use acrolein as model compound. However, particularly interesting and promising is the finding, as demonstrated in this experimental work, that M14 ADR2 cells were much more sensitive to the toxic metabolites of spermine than their wildtype counterpart.

The exposure of phosphatidylserine, a negative charged phospholipid, on the outer surface of the cytoplasmic membrane clearly showed the onset of the apoptotic process. Flow cytometric analysis was performed by Annexin V-FITC and propidium iodide (PI) assay (Fig. 2). The measurement of Annexin V binding, executed simultaneously with the exclusion dye PI, provided a suitable assay to detect apoptotic cells and to discriminate between apoptosis (both early and late) and necrosis. The cytotoxic products hydrogen peroxide and aldehyde(s) induced a significant increase of early apoptotic fraction on both cell lines $72 \mathrm{~h}$ after the end of the treatment (11.1\% in M14 WT and 23.7\%) in M14 ADR2 cells when compared to 1.5 and $7.3 \%$ in the respective control cells. Pre-treatment with CQ, followed by the treatment with spermine metabolites, enhanced the percentage of apoptotic cells on both lines: $17.5 \%$ on M14 WT but particularly on MDR cells, where it approximately doubled (48.1\%).

A further investigation on the cell cycle analysis by flow cytometry (Fig. 3), revealed that subG1 hypodiploid cells, a subpopulation of apoptotic cells with fragmented DNA, accumulated in response to the treatment of M14 WT and M14 ADR2 cells with BSAO and $6 \mu \mathrm{M}$ spermine or when both cells lines were pre-treated with CQ and then treated with $\mathrm{BSAO} /$ spermine enzymatic system. The increase of the subG1 fraction, induced by the oxidation products of spermine, was much higher in M14 ADR2 cells (approximately 2 times) than in M14 WT ones after the combined treatment. This finding is in agreement with the results obtained either by Annexin V-FITC/PI assay or TEM observations. Severe changes of the mitochondrial structure, such as dilatation of the cristae, disruption of membranes and chromatin condensation produced the characteristic apoptotic phenotype, were mainly observed in multidrug-resistant cells.

Taking into consideration the findings described above, the difference between MDR and WT melanoma cells in sensitivity to treatment with BSAO and spermine, particularly after sensitization with $50 \mu \mathrm{M} \mathrm{CQ}$, is evident, and explained as follows. Several human MDR tumour cells express P-glycoprotein, a membrane-bound transporter protein, which functions as energy-dependent pump capable of extruding drugs out of cells (46). However, P-glycoproteinmediated excretion of the toxic products of spermine oxidation appears to play no, or only a minor role, because M14 ADR2 cells were not less, but significantly more sensitive to exposure to BSAO and spermine than M14 WT cells. The higher sensitivity to cytotoxic spermine derivatives of colon adenocarcinoma LoVo DX cells, as compared with WT cells, has previously been attributed to an earlier and higher mitochondrial membrane depolarisation, and a higher basal production of ROS that was not related to the glutathione content, because MDR and WT LoVo cells have the same glutathione pool $(22,47)$. At present no data exist to allow to draw the same conclusion on M14 melanoma cells (our studies are in progress), although the same physiological factors are possibly responsible for the enhanced sensitivity in both MDR cell lines.

The evaluation of the apoptosis induction carried out by fluorescence microscopy after Hoechst 33258 staining supported the findings described above. Moreover, Hoechst assay confirmed the results obtained by the cytotoxicity MTT test. As reported in the Results, after treatment with spermine metabolites the nuclei of normal melanocytes (Fig. 8B) appeared to be unaltered when compared to those of control ones (Fig. 8A). Instead, after the same treatment numerous apoptotic nuclei were observed in both M14 WT and M14 ADR2 cell cultures, not detectable in the corresponding control ones.

In conclusion, from the enhanced sensitivity of immortalised cells to lysosomal death pathways (48),new possibilities in cancer therapy are expected (49). The sensitisation of tumour cells to anticancer drugs by lysosomotropic compounds, and particularly the sensitisation of MDR cells, recommend scrutinizing the potential of lysosomotropic drugs in cancer therapy. In clinical applications, the enhancement of the efficacy of in situ formation of cytotoxic polyamine metabolites, hydrogen peroxide and aldehyde enzymatically generated, deserves to be taken into consideration. Sensitising cells by a lysosomotropic compound, as for example chloroquine or MDL $72527(8,12)$, improved cell damage by hydrogen peroxide and other spermine metabolites, activating the stress signal transduction pathway and leading to apoptotic cell death. Therefore, an extension of these experiments with the aim to further improve the apoptotic effect of spermine metabolites appears important. In our opinion, the systematic exploration of chloroquine in combination with conventional anticancer drugs promises new and efficient anticancer therapies within a short period. It has been demonstrated that chloroquine has antiviral effects (50) and, more important, it improves the therapy of glioblastoma multiforme (51). Thus, the studies carried out in our laboratories on human colon adenocarcinoma and melanoma cells, suggest that the anti-malarial drug chloroquine, in association with $\mathrm{BSAO} /$ spermine, could potentiate the effects of the enzymatic oxidation products of spermine and might be important as a new approach in anti-neoplastic therapy, particularly against MDR cancer cells.

\section{Acknowledgements}

This study was partially supported by the Italian MIUR (Ministero dell'Istruzione, dell'Università e della Ricerca), by Istituto Superiore di Sanità 'Project Italy-USA', by funds MIUR-PRIN (Cofin) and by Istituto Pasteur-Fondazione Cenci Bolognetti. Thanks are also due to Fondazione 'Enrico ed Enrica Sovena' for the scholarships to Giampiero Tempera for supporting his post-doc (E.A.). 


\section{References}

1. La Porta CA: Mechanism of drug sensitivity and resistance in melanoma. Curr Cancer Drug Targets 3: 391-397, 2009.

2. Setia N, Abbas O, Sousa Y, Garb JL and Mahalingam M: Profiling of $\mathrm{ABC}$ transporters $\mathrm{ABCB} 5, \mathrm{ABCF} 2$ and nestin-positive stem cells in nevi, in situ and invasive melanoma. Mod Pathol 25: $1169-1175,2012$.

3. Davies MA: The role of the PI3K-AKT pathway in melanoma. Cancer J 18: 142-147, 2012.

4. Nikolaous VA, Stratigos AJ, Flaherty KT, et al: Melanoma: new insights and new therapies. J Invest Dermatol 132: 854-863, 2012 .

5. Goodwin AC, Jadallah S, Toubaji A, Lecksell K, Hicks JL, Kowaski J, Bova GS, De Marzo AM, Netto GJ and Casero RA Jr: Increased spermine oxidase expression in human prostate cancer and prostatic intraepithelial neoplasia tissues. Prostate 68: 766-772, 2008

6. Simoneau AR, Gerner EW, Nagle R, Ziogas A, Fujikawa-Brooks S, Yerushalmi H, Ahlering TE, Lieberman R, Mclaren CE, Anton-Culver $\mathrm{H}$ and Meyskens FL Jr: The effect of difluoromethylornithine on decreasing prostate size and polyamines in men: results of a year-long phase IIb randomized placebocontrolled chemoprevention trial. Cancer Epidemiol Biomarkers Prev 17: 292-299, 2008.

7. Gerner EW and Meyskens FL: Polyamines and cancer: old molecules, new understanding. Nat Rev Cancer 4: 782-792, 2004.

8. Agostinelli E, Belli F, Molinari A, Condello M, Palmigiani P, Dalla Vedova L, Marra M, Seiler N and Arancia G: Toxicity of enzymatic oxidation products of spermine to human melanoma cells (M14): sensitization by heat and MDL 72527. Biochim Biophis Acta 1763: 1040-1050, 2006.

9. Agostinelli E, Condello M, Molinari A, Tempera G, Viceconte N and Arancia G: Cytotoxicity of spermine oxidation products to multidrug resistant melanoma cells (M14 ADR2): sensitisation by MDL 72527, a lysosomotropic compound. Int J Oncol 35: 485-498, 2009.

10. Marra M, Agostinelli E, Tempera G, Lombardi A, Meo G, Budillon A, Abbruzzese A, Giuberti G and Caraglia M: Anticancer drugs and hyperthermia enhance cytotoxicity induced by polyamine enzymatic oxidation products. Amino Acids 33: 273-281, 2007.

11. Marra M, Lombardi A, Agostinelli E, Giuberti G, Zappavigna S, Tempera G, Vitale G, Bifulco M, Abbruzzese A and Caraglia M: Bovine serum amine oxidase and spm potentiate docetaxel and interferon-alpha effects in inducing apoptosis on human cancer cells through the generation of oxidative stress. BBA-Mol Cell Res 1783: 2269-2278, 2008.

12. Agostinelli E, Dalla Vedova L, Belli F, Condello M, Arancia G and Seiler N: Sensitization of human colon adenocarcinoma cells (LoVo) to reactive oxygen species by lysosomotropic compounds. Int J Oncol 29: 947-955, 2006.

13. Dai H, Kramer DL, Yang C, Murti KG, Porter CW and Cleveland JL: The polyamine oxidase inactivator MDL-72527 selectively induces apoptosis in transformed hematopoietic cells through lysosomotropic effects. Cancer Res 59: 4944-4954, 1999.

14. Iyamu E, Perdew H and Woods G: Growth inhibitory and differentiation effect of chloroquine and its analogue on human leukemic cells potentiate fetal hemoglobin production by targeting the polyamine pathway. Biochem Pharmacol 77: 1021-1029, 2009.

15. Turini P, Sabatini S, Befani O, Chimenti F, Casanova C, Riccio $P$ and Mondovi B: Purification of serum amine oxidase. Anal Biochem 125: 294-298, 1982

16. Janes SM, Mu D, Wemmer D, Smith AJ, Kaur S, Maltby D, Burlingam AL and Klinman JP: A new redox cofactor in eukaryotic enzymes: 6-Hydroxydopa at the active site of bovine serum amine oxidase. Science 248: 981-987, 1990

17. Molinari A, Toccaceli L, Calcabrini A, Diociaiuti M, Cianfriglia $M$ and Arancia G: Induction of P-glycoprotein expression on the plasma membrane of human melanoma cells. Anticancer Res 20: 2691-2696, 2000.

18. Molinari A, Calcabrini A, Crateri P and Arancia G: Interaction of anthracyclin with cytoskeletal components of cultured carcinoma cells (CG5). Exp Mol Pathol 53: 11-33, 1990.

19. van Engeland M, Nieland LJ, Ramaekers FC, Schutte B and Reutelingsperger CP: Annexin V-affinity assay: a review on an apoptosis detection system based on phosphatidylserine exposure. Cytometry 31: 1-9, 1998.
20. Nicoletti I, Migliorati G, Pagliacci MC, Grignani F and Riccardi C: A rapid and simple method for measuring thymocyte apoptosis by propidium iodide staining and flow cytometry. J Immunol Methods 139: 271-279, 1991.

21. Sharmin S, Sakata K, Kashiwagi K, Ueda S, Iwasaki S, Shirahata A and Igarashi K: Polyamine cytotoxicity in the presence of bovine serum amine oxidase. Biochem Biophys Res Commun 282: 228-235, 2001.

22. Calcabrini A, Arancia G, Marra M, Crateri P, Befani O, Martone A and Agostinelli E: Enzymatic oxidation products of spermine induce greater cytotoxic effects on human multidrugresistant colon carcinoma cells $(\mathrm{LoV})$ than on their wild-type counterparts. Int J Cancer 99: 43-52, 2002.

23. Agostinelli $E$ and Seiler N: Non-irradiation-derived reactive oxygen species (ROS) and cancer. Therapeutic implications. Amino Acids 31: 341-355, 2006.

24. Agostinelli E and Seiler N: Lysosomotropic compounds and spermine enzymatic oxidation products in cancer therapy (review). Int J Oncol 31: 473-484, 2007.

25. Agostinelli E, Przybytkowskj E, Mondovì B and Averill-Bates DA: Heat enhancement of cytotoxicity induced by oxidation products of spermine in Chinese hamster ovary cells. Biochem Pharmacol 72: 36-42, 1994.

26. Averill-Bates DA, Ke Q, Tanel A, Roy J, Fortier G and Agostinelli E: Mechanism of cell death induced by spermine and amine oxidase in mouse melanoma cells. Int J Oncol 32: 79-88, 2008.

27. Lord-Fontaine S, Agostinelli E, Przybytkowskj E and AverillBates DA: Amine oxidase, spermine, and hyperthermia induce cytotoxicity in P-glycoprotein overexpressing multidrug resistant Chinese hamster ovary cells. Biochem Cell Biol 79: 165-175, 2001.

28. Averill-Bates DA, Cherif A, Agostinelli E, Tanel A and Fortier G: Anti-tumoral effect of native and immobilized bovine serum amine oxidase in a mouse melanoma model. Biochem Pharmacol 69: 1693-1704, 2005.

29. Demers N, Agostinelli E, Averill-Bates DA and Fortier G: Immobilization of native and poly(ethylene glycol)-treated ('PEGylated') bovine serum amine oxidase into a biocompatible hydrogel. Biotechnol Appl Biochem 33: 201-207, 2001.

30. Gerner EW and Meyskens Fl Jr: Combination chemoprevention for colon cancer targeting polyamine synthesis and inflammation. Clin Cancer Res 15: 758-761, 2009.

31. Park BC, Park SH, Paek SH, et al: Chloroquine-induced nitric oxide increase and cell death is dependent on cellular GSH depletion in A172 human glioblastoma cells. Toxicol Lett 178: 52-60, 2008 .

32. Jiang $P$, Zhao $Y$, Shi $W$, et al: Cell growth inhibition, G2/M cell cycle arrest, and apoptosis induced by Chloroquine in human breast cancer cell line Bcap-37. Cell Physiol Biochem 22: 431-440, 2008.

33. Kimura T, Yoshitsugu T, Atsushi T, et al: Chloroquine in cancer therapy: a double-edged sword of autophagy. Cancer Res 73: 3-7, 2013.

34. Michaud M, Martins I, Sukkurwala AQ, Adjemian S, Ma Y, Pellegatti P, et al: Autophagy-dependent anticancer immuneresponses induced by chemotherapeutic agents in mice. Science 334: 1573-1577, 2011.

35. Amaravadi RK and Thompson CB: The roles of therapy-induced autophagy and necrosis in cancer treatment. Clin Cancer Res 13: 7271-7279, 2007

36. Tasdemir E, Galluzzi L, Maiuri MC, Criollo A, Vitale I, Hangen E, Modjtahedi $\mathrm{N}$ and Kroemer G: Methods for assessing autophagy and autophagic cell death. Methods Mol Biol 445: 29-76, 2008.

37. Vezmar M and Georges E: Reversal of MRP-mediated doxorubicin resistance with quinoline-based drugs. Biochem Pharmacol 59: 1245-1252, 2000.

38. Solomon VR and Lee H: Chloroquine and its analogs: a new promise of an old drug for effective and safe cancer therapies. Eur J Pharmacol 625: 220-233, 2009.

39. Homewood CA, Warhurst DC, Peters W and Baggaley VC: Lysosomes, $\mathrm{pH}$ and the anti-malarial action of chloroquine. Nature 235: 50-52, 1972.

40. Slater AF: Chloroquine: mechanism of drug action and resistance in Plasmodium falciparum. Pharmacol Ther 57: 203-235, 1993.

41. Agostinelli E, Tempera G, Dalla Vedova L, Condello M and Arancia G: MDL 72527 and spermine oxidation products induce a lysosomotropic effect and mitochondrial alterations on tumor cells. Biochem Soc Trans 35: 343-348, 2007. 
42. Guicciardi ME, Leist M and Gores GJ: Lysosomes in cell death. Oncogene 23: 2881-2890, 2004.

43. Zhao M, Antunes F, Eaton JW and Brunk UT: Lysosomal enzymes promote mitochondrial oxidant production, cytochrome c release and apoptosis. Eur J Biochem 270: 13778-13786, 2003.

44. Yu Z, Li W and Brunk UT: 3-Aminopropanal is a lysosomotropic aldehyde that causes oxidative stress and apoptosis by rupturing lysosomes. APMIS 111: 643-652, 2003.

45. Zdolsek J, Zhang $\mathrm{H}$, Roberg $\mathrm{K}$ and Brunk U: $\mathrm{H}_{2} \mathrm{O}_{2}$-mediated damage to lysosomal membranes of J-774 cells. Free Radic Res Commun 18: 71-85, 1993

46. Gottesman MM and Pastan I: Biochemistry of multidrug resistance mediated by the multidrug transporter. Ann Rev Biochem 62: 385-342, 1993

47. Arancia G, Calcabrini A, Marra M, Crateri P, Artico M, Martone A, Martelli F and Agostinelli E: Mitochondrial alterations induced by serum amine oxidase and spermine on human multidrug resistant tumor cells. Amino Acids 26: 273-282, 2004.
48. Fehrenbacher N, Gyrd-Hansen M, Poulsen B, Felbor U, Kallunki T, Boes M, Weber E, Leist M and Jäättelä M: Sensitization to the lysosomal cell death pathway upon immortalization and transformation. Cancer Res 64: 5301-5310, 2004.

49. Fehrenbacher N and Jäättelä M: Lysosomes as targets for cancer therapy. Cancer Res 65: 2993-2995, 2005.

50. Savarino A, Lucia MB, Giordano F and Cauda R: Risks and benefits of chloroquine use in anticancer strategies. Lancet Oncol 7: 792-793, 2006.

51. Briceño E, Reyes S and Sotelo J: Therapy of glioblastoma multiforme improved by the antimutagenic chloroquine. Neurosurg Focus 14: e3, 2003. 